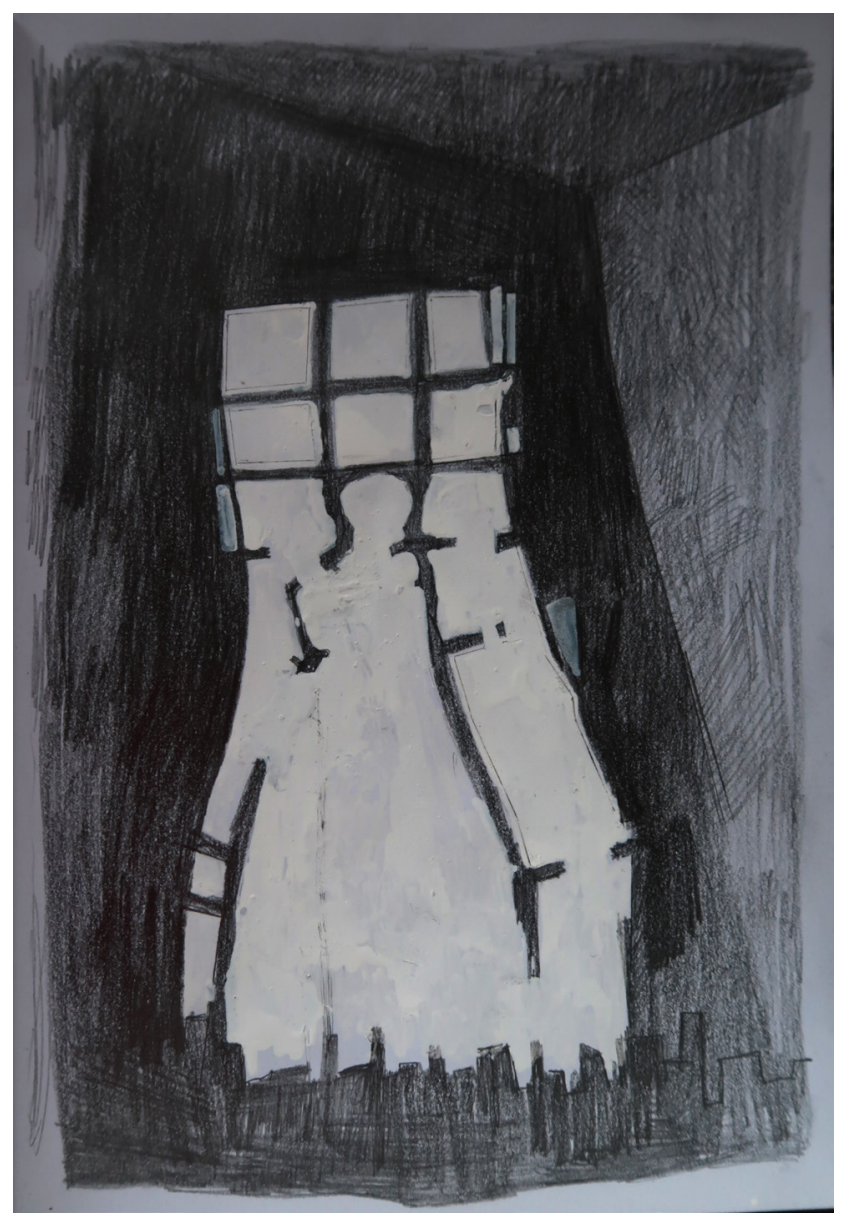

\title{
Adentros que se afueran
}

Junio 2020

\section{Técnica}

Grafito sobre papel y tipex.

\section{Reflexión}

La pandemia nos dictaminó un confinamiento domiciliario interminable, una distancia de todo lo humano. Para equilibrar de nuevo el mapa me he liberado de lastres nada lustrosos regalándome la libertad de liderar el trazo de mis lápices.

\section{Autor}

David Gamella. Musicoterapeuta (UAM). Director Máster Musicoterapia UNIR. https://orcid. org/0000-0001-9834-954X

Profesor Didáctica de la Expresión Plástica. CUCC (UAH)

Arteterapia: papeles de arteterapia y educación artística para la integración social.

Monográfico: Las miradas del arte y el arteterapia en tiempos de la Covid19. ISSN-e: 1988-8309 https://dx.doi.org/10.5209/arte.75932 